удк 330.14

JEL Classification: D 24

DOI: https://doi.org/10.35774/visnyk2020.03.185

\title{
Оксана ЯВОРСЬКА,
}

кандидат біологічних наук, доцент, доцент кафедри туризму,

Київський національний лінгвістичний університет,

вул. Вел. Васильківська, м. Київ, 7303151, Україна, e-mail: yavorska-oksana@ukr.net

ORCID iD: https://orcid.org/0000-0002-4499-6853

\section{ЗНАННЯ ЯК КОМПЛЕМЕНТАРНА СКЛАДОВА ІНТЕЛЕКТУАЛЬНОГО КАПІТАЛУ ПІДПРИЄМСТВА В ЕПОХУ ЦИФРОВОЇ ЕКОНОМІКИ}

Яворська О. Знання як комплементарна складова інтелектуального капіталу підприємства в епоху цифрової економіки. Вісник Тернопільського національного економічного університету. 2020. Вип. 3. C. 185-198. DOI: https://doi.org/10.35774/ visnyk2020.03.185

Yavorska, O. (2020). Znannia yak komplementarna skladova intelektualnoho kapitalu pidpryiemstva $v$ epokhu tsyfrovoi ekonomiky [The knowledge as a complementary part of the intellectual capital of the enterprises in the era of the digital economy]. The Herald of Ternopil National Economic University, Vol. 3. P. 185-198. DOI: https://doi.org/10.35774/ visnyk2020.03.185

\section{Анотація}

Вступ. Розглянуто проблему основних змін, які очікуються з розвитком цифрової економіки. Особлива увага в цих умовах приділяється сфрері трансформації капіталу знань як складової інтелектуального капіталу підприємства. Джерелом розвитку сучасної цифрової економіки варто вважати інтелектуальний капітал підприємства, який базується на комбінованому використанні нематеріальних активів і інфрормаційних ресурсів організацій. Формування інтелектуального капіталу підприємства розәлядається з системної точки зору та у поєднанні з формуванням капіталу знань компаній і фрірм.

Метою cmammi є визначення відмінної ролі корпоративних знань у фрормуванні інтелектуального капіталу підприємства в умовах цифрової економіки, обгрунтування принципу комплементарності у траєкторії сучасних трансфрормацій знаннєвого капіталу організації в межах концепції інтелектуального капіталу підприємства.

Методи дослідження. У роботі були використані загальнонаукові та спеціальні методи дослідження (історичний, логічний, аналізу, синтезу, графрічної побудови, наукової абстракції).

(C) Оксана Яворська 2020. 
Результати. У статmі представлено авторський погляд на виникнення капіталу знань підприємств у контексті сорормованих економічних теорій і на основі аналізу еволюції категорії «знання». Уточнено роль знаннєвого капіталу для інтелектуального капіталу підприємства та його складові в організаційному, реляційному i людському капіталах суб'єктів підприємницької діяльності. Результати дослідження мають важливе значення для вчених, економістів та експертів з управління інтелектуальним капіталом підприємств, корпорацій і форм, їх можна використовувати в процесі розробки організаційних методів та удосконалення політики управління людськими ресурсами організацій.

Перспективи. Провідним вектором розвитку інтелектуального капіталу підприємств в умовах цифрової економіки мають стати питання проєктування процесу кумуляції, класифрікації, вимірювання та трансформатизації знаннєвого капіталу, а такожрозробка інструментів переводу його елементів уматеріалізовані та інноваційні активи організації.

Ключові слова: інтелектуальний капітал; знаннєвий капітал; інноваційні знання, цифрова економіка.

Формул: 0, рис.: 2, табл.: 0, бібл.: 31.

\section{Abstract}

\section{Oksana YAVORSKA}

\section{THE KNOWLEDGE AS A COMPLEMENTARY PART OF THE INTELLECTUAL CAPITAL OF THE ENTERPRISES IN THE ERA OF THE DIGITAL ECONOMY}

Introduction. The article deals with the problem of the main changes expected in the framework of the digital economy are considered. Particular attention is paid to the areas of transformation the knowledge capital in these conditions. A driver of modern digital economy should be regarded as an intellectual capital that based on the combined use of the intangible assets and the information resources of the enterprises. The formation of the intellectual capital of a company is viewed from a systemic perspective and in conjunction with the formation of the knowledge capital of the enterprises.

Purpose. The purpose of our article is to determine the distinctive role of corporate knowledge in the formation of the intellectual capital of the enterprise in the digital economy, substantiation of the principle of complementarity in the trajectory of modern transformations of knowledge capital of the organization within the concept of the intellectual capital.

Methods. We have used a set of general and special methods in this article (they are historical and logical method, method of analysis and synthesis, grafhic constraction, scientific abstraction).

Results. The article presents the author's view on the emergence of the knowledge capital of the enterprises in the context of the prevailing economic theories, based on an analysis of the evolution of the category «knowledge». The role of knowledge capital for the intellectual capital of the enterprises and its essence in the relational (customer) capital, organisational capital and human capital of the company, firms. The carried-out analysis and synthesis of the existing approaches on studying of intellectual capital of the enterprises taking into account specifics of the knowledge capital of the company are used 
to support existing managerial policies for better retention practices and management of human resources, for better management practices of the enterprises.

Prospects. The leading vector for the development of the intellectual capital of the enterprises in the digital economy should be the question of designing the process of cumulation, classification, measurement and transformation of knowledge capital, as well as the development of tools for translating its elements into materialized and innovative assets of the organization.

Keywords: intellectual capital, knowledge capital, innovative knowledge, digital economy.

Formulas: 0, fig.: 2, tabl.: 0, bibl.: 31 .

Постановка проблеми. Розвиток цифрової економіки сприятиме появі значної кількості нових економічних можливостей для підприємств: забезпечення зростання їхніх економічних та соціальних показників, розвитку інноваціності та підвищення продуктивності праці, виходу на нові ринки в результаті діджиталізації та трансформації останніх, а модифікація ланцюгів креації вартості у різний спосіб створить нові вектори для примноження доданої вартості, що зумовить необхідність більш швидких та масштабних структурних змін організацій [1; 2, с. 1170]. В епоху трансформації галузей від трудомістких до знаннєвих підприємства все більше залежатимуть від нематеріальних активів, у т. ч. знання, водночас кінцевий результат буде залежати від рівня розвитку інтелектуального капіталу організації.

Аналіз останніх досліджень і публікацій. За два останніх десятиліття в науковій літературі висвітлювалися результати практик та методів управління знаннями на підприємствах, проте, незважаючи на позитивний взаємозв'язок таких практик та суб'єктивних оцінок діяльності організацій, деякі автори висловлюють занепокоєння щодо достовірності таких (з огляду на методологічні проблеми розробки) практик 3 управління людськими ресурсами і знаннями у підприємствах [3, с. 64; 2, с. 1173; 4 , с. $351 ; 5$, с. 47]. Водночас, оптимізм щодо потенціалу методів управління знаннями з метою підвищення ефективності праці співробітників стимулював появу нових теоретичних та емпіричних досліджень. Науковці різних наукових напрямів і дисциплін запропонували різні концептуальні рамкидля виявлення та обґрунтування кореляції між інтелектуальним капіталом підприємства та економічними результатами на мікрорівні в теорії систем, інституціональної теорії, теорії ресурсної залежності й інших, а також концепції інтелектуального капіталу підприємства. Управління знаннями, як методика управління нематеріальними активами виявилася ефективною для досягнення конкурентних переваг підприємств, що засновані на інтелектуальному капіталі в епоху цифрової економіки [6, с. 62; 2, с. 1171]. Дані, інформація та знання становили новий економічний ресурс, необхідний для створення вартості та отримання вигод; здатність контролювати їх має стратегічно важливе значення, оскільки це дає змогу трансформувати їх у «цифровий інтелект» [7; 8, с. 937]. Практично у всіх ланцюгах створення вартості здатність збирати, зберігати, аналізувати та трансформувати знаннєво-інформаційні ресурси посилює вплив підприємств на ринку та створює конкурентні переваги. Підприємства змушені докорінно змінювати способи ведення бізнесу, а також вибудовувати новітні бізнес-моделі за сучасних умов глобальної діджиталізації [9]. Розробка надійних і дієвих систем управління знаннями та 
інтелектуальним капіталом підприємства $€$ основним завданням для науковців, які зацікавлені в розвитку цього напряму досліджень.

Проблеми, які ще не досліджені. Провідними інструментами механізму примноженнязнаннєвого капіталупідприємстваєнематеріальніактиви, якіне окреслені ринковою вартістю за відсутності їхнього належного обліку та методів оцінювання як загалом, так і окремих параметрів, а також дотепер не вирішено питання щодо забезпечення належної економіко-правової безпеки усіх складових інтелектуального капіталу підприємства. Специфіка знання та інформації як складової інтелектуального капіталу підприємства полягає у тому, що такі активи розглядаються як безкінечні та невичерпні види ресурсу, які виступають результатом інтелектуальної діяльності висококваліфікованих та креативних працівників; їм притаманні такі властивості, як накопичення та примноження. Трансформація цих ресурсів генерує нові форми його використання та представлення, що забезпечує комерційний успіх сучасного бізнесу. Поширення інноваційних знань в організації бізнес-процесів підприємства сприяє раціональному та більш ефективному використанню матеріальних та фінансових видів капіталів організації. Відтак, актуалізуються та потребують вирішення питання проектування процесу примноження знаннєвого капіталу підприємства.

Метою дослідження євизначення відмінної ролі корпоративнихзнань у формуванні інтелектуального капіталу підприємства в умовах цифрової економіки, обґрунтування принципу комплементарності у траєкторії сучасних трансформацій знаннєвого капіталу організації у межах концепції інтелектуального капіталу підприємства.

Виклад основного матеріалу. Кількість зайнятих у секторі інформаційнокомунікаційних технологій (ІКТ) у світі зросло з 34 млн осіб у 2010 р. до 39 млн осіб у 2015 р., причому найбільший процент зайнятих (38\%) працює у сорері комп'ютерних послуг; за цей самий період частка сектору ІКТ у загальній зайнятості зросла з 1,8\% до $2 \%$ [10]. За оцінками Accenture Strategy, зростання рівня використання цифрових технологій примножить на 1 трлн 360 млрд доларів ВВП провідних світових економік у 2020 р. (Китаю - 418 млрд дол., США - 365 млрд дол., Японії - 114 млрд дол.) [11]. Компанії, які інвестують в інформаційно-комунікаційні технології $€$ більш прибутковими, конкурентоздатними та економічно ефективними. В умовах цифрової економіки саме знання визнані провідною рушійною силою економічного зростання, що акцентувало питання оцінювання та примноження інтелектуального капіталу підприємства, зокрема таких його складових, як цифрові ресурси (охоплюють дані, інформацію, знання та інформаційні технології) та людський капітал як носія знань. У загальній структурі генерації та збереження даних збільшується роль корпоративних ПК, оскільки підприємства намагаються надавати інформацію та послуги у режимі реального часу (рис. 1). Також прогнозується, що у 2020-2022 рр. інформація, надана у форматі «Real-Time», зростатиме у 1,5 разу швидше, ніж розмір загальносвітових даних [10]. 


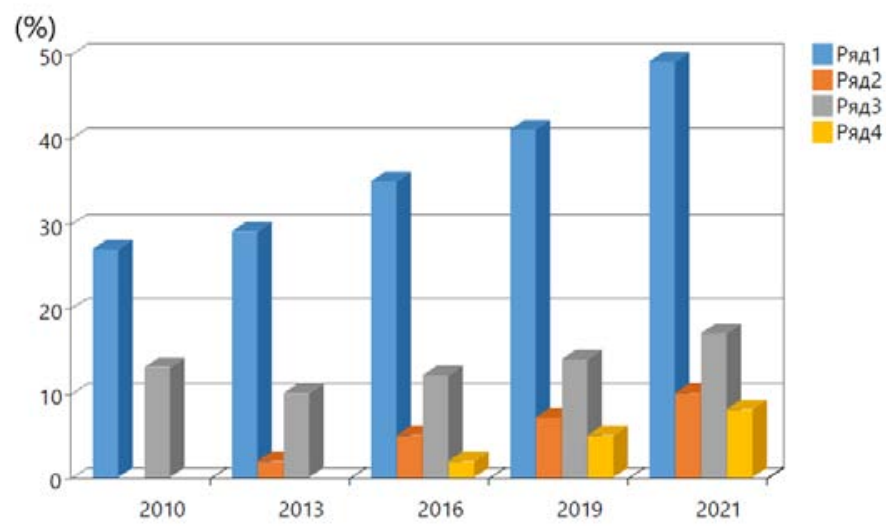

Рис. 1. Основні платформи для генерації та зберігання даних

Примітка. Ряд: 1 - частка корпоративних даних; 2 - частка даних на мобільних пристроях; 3 - частка цифрових даних від загальної глобальної сфери даних; 4 частка даних у форматі реального часу («Real-Time Data»).

Джерело: розроблено автором за [10].

Цифрова економіка продовжує розвиватися з неймовірною швидкістю завдяки їі здатності збирати, використовувати та аналізувати величезні обсяги цифрових даних. Обсяг глобального трафіку на основі Інтернет-протоколу (IP), який дає змогу приблизно уявити масштаби потоку даних, зріс у 2017 р. до 46000 ГБ за секунду, а згідно з прогнозам, у 2022 р. становитиме 150000 ГБ за секунду за рахунок появи все більшої кількості нових користувачів Інтернет-мережі та розширення Інтернет товарів $[1 ; 12]$. Вплив, який створюють процеси кумуляції та використання даних на процес розвитку економіки значною мірою залежить від типу відповідних даних, інформації та знання: персональні, публічні, конфіденційні, комерційні, надані добровільно, отримані в результаті спостереження, аналітично екстрапольовані тощо. 3'являються нові «ланцюги створення вартості даних», складовими яких виступають підприємства. Формування інфраструктури, яка необхідна для генерування нових знань та розвитку технологій, збільшення потоку даних та розвитку методів їхнього аналізу, діджиталізації, підвищенні рівня доступності інформації, трансформування та покращення бізнеспроцесів компаній світу відбувається за рахунок найважливішого ресурсу організацій інтелектуального капіталу. Ми приймаємо модель інтелектуального капіталу підприємства, яка на сьогодні визнана традиційною і охоплює такі основні складові: людський капітал, клієнтський (або реляційний) капітал та організаційний (або структурний) капітал [13, с. $27 ; 14 ; 15]$.

Вважаємо за доцільне розпочати огляд джерел з твердження відомого популяризатора концепції інтелектуального капіталу підприємства Т. Стюарта, який серед перших окреслив основну складову інтелектуального капіталу підприємства суму всіх корисних знань, яку формують усі працівники організації і яка становить основу конкурентних переваг компаній на ринку [14]. Такої думки згодом дотримувався Л. Едвінсон, зазначаючи, що саме знання, якими володіє організація, є цінними, 
якщо вони «конвертуються у надбання компанії»; або, як доводили С. Гаррісон, П. Салліван та інші, ті «знання, які трансформуються в прибуток»; Н. Бреннан, Б. Коннел та інші також розглядали «знання як капітал підприємства»; Н. Бонтіс у складі інтелектуального капіталу підприємства виокремив знаннєвий капітал двох рівнів: «знання працівників та загальноорганізаційні знання, що генерують конкурентні переваги компаній» [16, с. 62; 3, с. 65; 17; 18, с. 216; 15, с. 63; 19, с. 38]. В літературі можна зустріти концептуалізацію інтелектуального капіталу як суму всіх знань, які можуть бути використані організаціями в пошуку їхньої конкурентної переваги; Дж. Нехейпіт і С. Гошаль інтелектуальний капітал визначають як тип знань та пізнавальну здатність соціального колективу. Проте більшість дослідників розглядаючи інтелектуальний капітал як цінний ресурс, ототожнюють його з нематеріальними активами, що пов'язані із знаннями, якими володіє організація [20]. Власне з кінця 80-х років XX ст. і до поатку XXI ст. поняття інтелектуального капіталу підприємства, переважно, трактувалось як сума всіх знань (знання працівників, технології, інновації, інформація про стейкхолдерів, партнерів, споживачів та клієнтів, елементи стратегічного менеджменту тощо), які в запропонованих вченими моделях нематеріальних активів та інтелектуального капіталу підприємства були структуровані по-різному, проте характеризувалися тим, що забезпечували підприємству конкурентні переваги на ринках.

Українські дослідники також схиляються до думки, що інтелектуальний капітал підприємства варто ототожнювати зі знаннями в широкому розумінні. Глибинним наповненням інтелектуального капіталу, на думку О. В. Літвінова та багатьох науковців, і дотепер виступають саме «знання, які уособлені в людському капіталі, технологічному капіталі, капіталі відносин із оточенням (реляційний капітал) та організаційному капіталі підприємства; а інтелектуальний капітал підприємства визначається, як сукупність соціально-економічних відносин, які пов'язані із формуванням, використанням та відновленням знань» [21, с. 101]. Деякі наші науковці стверджують, що основними цінностями інтелектуального капіталу є «лише знання, інші - знання та інформація» [22, с. 26]. Нематеріальність знань, умінь та кваліфікації, на відміну від патентів, винаходів тощо, на які можна встановити право власності, не зменшують цінність цих активів для підприємства (як для формування фрінансових результатів, так і для вартості підприємства загалом) [3, с. 65].

Сучасний менеджмент управління знаннями пропонує такі види знань: індивідуальні та колективні, а також всі форми знань для креації цінностей [6, с. 52]. Як зазначає О. М. Собко, «для розвитку індивідуального інтелектуального капіталу стратегічним ресурсом $€$ не стільки знання, а капітал знань (концепційна здатність сформованих людиною теоретичних, прикладних і духовних знань генерувати інтелектуальні продукти та створювати додану вартість), якісні можливості якого визначаються такими рівнями знань людини:

- теоретичних (рівень освіти, володіння мовами, обізнаність з інформаційними технологіями);

- прикладних (рівень фахової підготовки, якість баз практик і стажувань) забезпечують рівень фахової підготовки спеціаліста;

- духовних (моральні та культурні цінності) - забезпечують активізацію людського чинника, підвищують продуктивність праці [13, с. 67-69]. 
В. Г. Когденко, аналізуючи Міжнародний стандарт інтегрованої звітності, звертає увагу на наявність фракту «неконтрольованого знання». Він визначає цей елемент як «основну цінність людського капіталу; інтелектуальний капітал - знання, які можна контролювати через систему їх генерування, поширення та творчого використання» [16, с. 60].

Більш комплексне бачення цього питання допускає, що «інтелектуальний капітал як складова нематеріальних ресурсів підприємства $є$ сукупністю явних та неявних, формалізованих та неформалізованих знань, які об'єднують все, що має вартість для підприємства, а також працівників; і здатне виникати з виробничих процесів, систем або організаційної культури» - таке трактування цінне тим, що У. Букович та Р. Уильямс вказують джерела формування знаннєвого капіталу компаній та фрірм [23, с. 21]. І. Нонака і Г. Такеучі запропонували декомпозицію знань у вигляді двох класів: формалізовані та неформалізовані, обґрунтувавши це тим, що саме формалізовані знання (на відміну від неформалізованих) можуть трансформуватися в інформацію та передаватися від суб'єкта до об'єкта; а також розробили управлінську модель постійного оновлення знань шляхом взаємодії між мовчазним та явним знанням у соціальному контексті; розглядали мовчазне знання як особистісне, специфічне для контексту, а тому складне для прямої формалізації [24, с. 143]. Д. Андріссен та Р. Тіссен також назвали п'ять груп нематеріальних активів підприємства, виокремивши неформалізовані знання та формалізовані знання [25, с. 13]. Деякі автори використовують метафори матеріалізації та неусвідомлення, де знання охоплюють думки та почуття («мовчазне знання» - доволі інтенсивно використовується); знання як світло («невідображене знання»); знання як процес; знання як інструмент («інтелектуальні інструменти») та знання як об'єкт («зібрати нові знання», «втратити старі знання» та «знання можуть бути поширеними») [17]. У К.-Е. Свейбі ця метафора чітко відображає в конкретному використані терміна «нематеріальні ресурси», оскільки актив - це особлива фрорма ресурсу; а інформація (явне знання) є лише одним елементом компетенції [26, с. 27]. Окремі дослідники розглядають неявні знання як результат екзистенціального пізнання, що власне $є$ здатність суб'єкта безперервно відтворювати каузальні зв'язки у межах вроджених та набутих властивостей [6, с. 51]. Виявом неявних знань вважаються психологічні, ментальнозмістові умови та фактори, раціональні очікування, численні системні психічні та соціальні явища [27, с. 27]. Раціональні очікування $€$ результатом «згустку» неявного знання у фрормі компетенцій про те, як варто всебічно аналізувати соціально-економічну дійсність. Функцією неявних знань, які формуються економічними агентами, можна розглядати як систему довірливих відношень; інтуіцію як унікальну компетенцію, що становить метод вирішення творчо-трудових завдань шляхом одномоментного підсвідомого умовиводу, яке збагачується уявою та попереднім досвідом людини, ступенем розвитку її емпатії, професійним чуттям та проникливістю [6, с. 53]. Варто зазначити, що сьогодні дослідники піднімають питання розвою парадигми «знання як інформації» та «знання як об'єкта» у сфері інтелектуального капіталу підприємства та закликають до обміну думок між вченими різних культур: «сподіваємося, що обмін накопиченим досвідом з питання інтелектуального капіталу сприятиме появі незахідних концепцій інтелектуального капіталу підприємств, які спонукають до крос- 
культурного дослідження» [17; 26, с. 25]. Досягнення успіху в сучасному глобальному середовищі з високим ступенем інтернаціоналізації бізнесу все більше обумовлене розвитком соціальних здібностей с персоналу фірми чи компанії, «м'яких навичок» (soft skills) та суспільно-культурних знань [28].

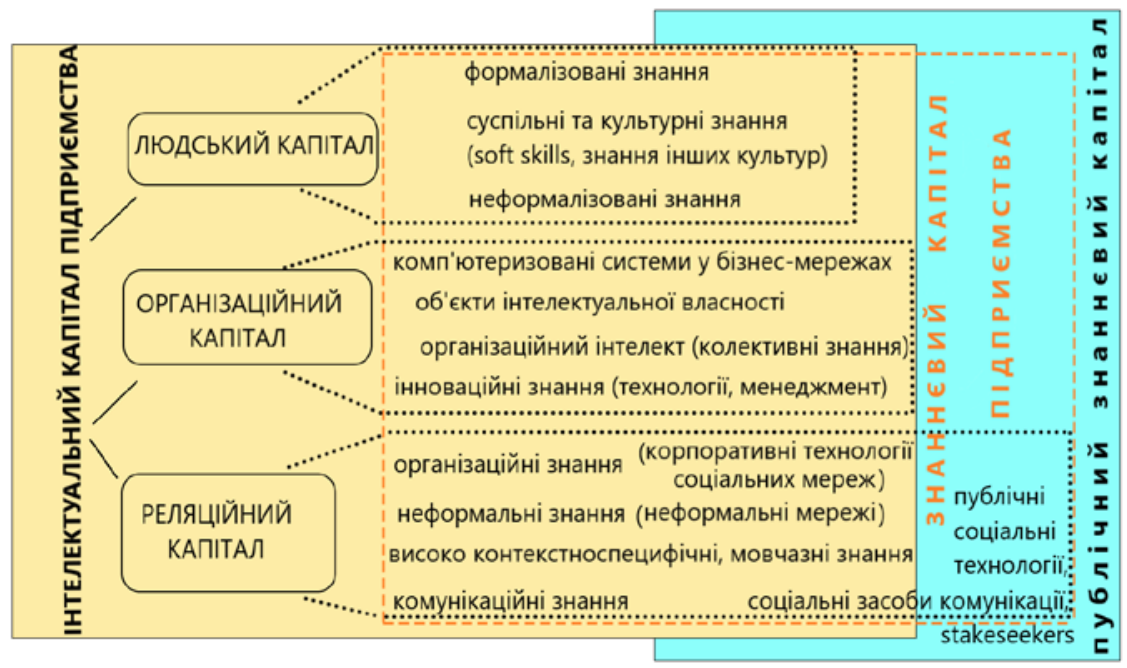

Рис. 2. Модель знаннєвого капіталу підприємства в умовах цифрової економіки Джерело: розроблено автором за [6, 13, 15, 20, 23, 26, 27, 30].

На нашу думку, капітал (рис. 2), входить до складу організаційного, реляційного (клієнтського) та людського капіталів, які загалом, формують інтелектуальний капітал підприємства. Організаційний капітал забезпечує безперервну генерацію нових ідей та знань, що можна об'єктивувати в кінцеві інноваційні продукти [17, с. 61]. Доведено, що темпи економічного зростання прямо залежать від величини людського капіталу, яке акумулюється у сфері отримання нового знання; основою застосування будьякого методу оцінювання ефективності досліджень та розробок має бути кадрова складова, що підлягає обліку та прогнозуванню на всіх рівнях управління [29, с. 79]. Окрім індивідуальних знань працівників, які становлять людський капітал; знання, які сприяють розвитку комунікаційних здібностей, примножують реляційний капітал (soft skills, зв'язки з клієнтами, постачальниками, стейкхолдерами; розкриття інформації про підприємство; знання про покращення репутації). «Stakeseekers» термін запропонований Дж. Думай згідно з концепцією ненавмисного розкриття інформації - «involuntary intellectual capital disclosure (ICD)», для соціогруп, які не мають прямого впливу на компанії (не виступають інвесторами, співвласниками тощо), але ставлять питання про розкриття інформації щодо соціальної та екологічної діяльності підприємств і водночас знаходяться за межами можливого контролю щодо них корпорацій та фрірм [30]. 3 різкою зміною технологічного ландшафту, цифрових трансформацій у середині і поза підприємством, можливістю широкого доступу до десятків соціальних технологій, розширився спектр інструментів спілкування та обміну знаннями як зі своїми колегами в організації, так і в процесі реалізації некорпоративних соціальних та професійних контактів. Вважається, що потенційні переваги новітніх 
технологій є нематеріальними, насамперед, сприяють зростанню людського капіталу [31]. Публічні соціальні технології та корпоративні технології соціальних мереж виявилися життєздатною платфрормою, на якій розбудовується соціальна взаємодія між людьми, а також примножується інтелектуальний капітал підприємства. Як вбачається із запропонованої моделі знаннєвого капіталу підприємства, формування інтелектуального капіталу організації має системний характер, а примноження його основних складових: людського капіталу, організаційного (або структурного) капіталу та клієнтського (або реляційного) капіталу, в умовах цифрової економіки відбувається за принципом комплементарності.

Висновки та перспективи подальших досліджень. Актуалізація важливості знаннєвого капіталу для сучасних підприємств полягає у тому, що існуючі знання про корпоративний успіх і механізми економічної ефективності підприємства навіть з недалекого минулого, нині, в кращому разі, виявляються не суттєвим, а в гіршому - небезпечно дезорієнтуючими (неадекватними). Унеможливлення подібних ситуацій можна досягнути за умов дотримання принципу комплементарності зростання сучасного знаннєвого капіталу та трансформації інтелектуального капіталу підприємства. Нова економіка у межах наукової парадигми відрізняється від традиційної тим, що в процесі її функціонування вищими темпами зростає частка інтелектуальної власності у створенні нової власності та примноженні прибутку підприємств, а знання та інформація стають визначальними факторами розвитку виробництва; підприємці є основними чинними особами економічної системи, яка заснована на цифризації та забезпеченні впровадження інновацій. У моделі цифрової економіки основна додана вартість створюється за допомогою фрактору «знання», а економічна перевага оцінюється з огляду на позицію в шкалі лідерства з випуску наукомісткої продукції та контролю інформаційних потоків.

Також, згідно з вищенаведеною та опрацьованою літературою щодо цього питання, можна зробити висновок, що межі дисциплінарної сфери знаннєвого капіталу інноваційної економіки є розмитими, а встановлення таких є обмежувально небезпечним для креації інтелектуального капіталу підприємства. Знаннєвий капітал не має автономного поля окремо від сфери управління, організації бізнеспроцесів, стратегічного планування, репутації, корпоративної культури та будь-яких інших сфер підприємства. Відтак, саме такий актив організації виступає провідною детермінантою примноження інтелектуального капіталу підприємства і основні завдання, які потребують подальшого вирішення, охоплять питання ідентифікації, класифікації, керування, вимірювання та прогнозування напрямів розвитку цього активу в організаціях. Перспективним вектором розвитку такого виду капіталу в умовах цифрової економіки мають стати питання проєктування процесу кумуляції та трансформатизації знаннєвого капіталу, а також розробка інструментів переведення його елементів у матеріалізовані та інноваційні активи організації.

\section{תimepamyра}

1. Доклад о цифровой экономике 2019. Создание стоимости и получение выгод: последствия для развивающихся стран. URL: https://www.google.com/url?s a=t\&source=web\&rct=j\&url=https://unctad.org/en/PublicationsLibrary/der2019_ 
overview_ru.pdf\&ved=2ahUKEwiJ8bOk5-_oAhWEs4sKHYKwAM8QFjAGegQIAR AB\&usg=AOvVaw1ki0mE (дата звернення: 5.04.2020).

2. Barkhordari S., Fattahi M., Azimi N. The Impact of Knowledge-Based Economy on Growth Performance: Evidence from MENA Countries. Journal of the Knowledge Economy. 2019. № 3 (10). P. 1168-1182. URL: https://doi.org/10.1007/132-018052-4 (дата звернення: 5.04.2020).

3. Торба О. В. Інтелектуальний капітал як об'єкт бухгалтерського обліку: визначення та методика оцінки. Інтернаука. 2017. № 2 (2). С. 62-67.

4. Karimi J., Walter Z. Corporate entrepreneurship, disruptive business model innovation adoption, and its performance: the case of the newspaper industry. Long Range Planning. 2016. № 3(49). P. 342-360.

5. Zambon $\mathrm{S}$. Is there a disciplinary field called «intangibles and intellectual capital»? Journal of Intellectual Capital. 2006. № 4 (7). P. 43-52. URL: https://doi.org/10.1108/ jic.2006.25007daa.001 (дата звернення: 11.04.2020).

6. Салихов Б. В., Салихова И. С., Олигова М. Б. Качество ключевых форм неявного знания в создании добавленной стоимости. Национальные интересы: приоритеты и безопасность. 2017. № 1 (346). С. 48-61.

7. Fekri Ali Sh. The board monitoring committees: an intellectual capital perspective. International Journal of Learning and Intellectual Capital (IJLIC). 2019. № 4 (16). URL: http://www.inderscience.com/info/ inarticle.php?artid=102632. (дата звернення: 12.04.2020).

8. Yu D., Zhou R. Intellectual Management: An Integrative Theory. Journal of the Knowledge Economy. 2017. № 3 (8). C. 929-956.

9. Faizi W. S.M., Imamul H. Intellectual capital and corporate financial performance in India's central public sector enterprises. International Journal of Learning and Intellectual Capital (IJLIC). 2020. № 1 (17). URL: http://www.inderscience.com/ info/inarticle.php?artid=105323. (дата звернення: 5.04.2020).

10. Reinsel, D., Gantz, J., and Rydning, J. (2017) Data Age 2025: The Evolution of Data to Life-Critical. Don't Focus on Big Data; Focus on the Data That's Big. URL: https:// assets.ey.com/content/dam/ey-sites/ey-com/en_gl/topics/workforce/Seagate-WPDataAge2025-March-2017.pdf. (дата звернення: 09.04.2020).

11. Цифризация экономики знаний. URL: https://old.sk.ru/news/b/articles/ archive/18/04/20/cifrovizaciya-ekonomiki-znaniy.aspx (дата звернення: 5.04.2020).

12. Reinsel, D., Gantz, J., and Rydning, J. (2018), Data Age 2025: The Digitization of the World. From Edge to Core. URL: https://www.seagate.com/files/www-content/ our-story/trends/files/idc-seagate-dataage-whitepaper.pdf (дата звернення: 13.04.2020).

13. Собко О.М. Інтелектуальний капітал підприємства : концептуалізація функціонування - розвиток : монографія. Тернопіль : Крок, 2014. 360 с.

14. Стюарт Т. Интеллектуальный капитал. Новый источник богатства организации. Москва : Academia, 1999. 433 c.

15. Edvinsson L., Malone M.S. Intellectual Capital, Harper Business, New York, 1997. 
16. Когденко В. Г. Анализ интегрированной отчетности: интеллектуальный капитал. Экономический анализ: теория и практика. 2016. № 10. С. 53-67.

17. Andriessen D. Intellectual capital: West-bound or East-bound?. Journal of Intellectual Capital. 2008. № 2 (9). URL: https://doi.org/10.1108/jic.2008.25009baf.002 (дата звернення: 10.04.2020).

18. Brennan N., Connell B. Intellectual capital: current issues and policy implications. Journal of Intellectual Capital. 2000. № 3 (1). P. 206-240.

19. Harrison S., Sullivan P. Profiting from intellectual capital - learning from leading companies. Journal of Intellectual Capital. 2000. № 1 (1). P. 33-46.

20. Li Y., Song Y., Wang J., Li C. Intellectual Capital, Knowledge Sharing, and Innovation Performance: Evidence from the Chinese Construction Industry. Sustainability. 2019. № 11(2713). URL: https://doi.org/10.3390/su11092713 (дата звернення: 14.04.2020).

21. Літвінов О.В.Визначення сутності інтелектуального капіталу. Modern Economics. 2018. № 11. C. 98-104. URL: https://doi.org/10.31/modecon.V11(2018)-16 (дата звернення: 11.04.2020).

22. Топільницька Я. О. Інтелектуальний капітал: суть та методика вимірювання. Держава та регіони. 2013 р. № 2 (71). С. 25-28.

23. Букович У., Уильямс Р. Управление знаниями: руководство к действию. М.: ИНФРА-М, 2002. 504 c.

24. Nonaka I., Takeuchi H. The Knowledge Creating Company. New York : Oxford University Press, 1995. 299 p.

25. Андриссен Д., Тиссен Р. Невесомое богатство. Определите стоимость вашей компании в экономике нематериальных активов. М.: ЗАО «Олимп-Бизнес», 2004. 304 c.

26. Sveiby K.E. The New Organizational Wealth: Managing \& Measuring Knowledgebased Asset. Berrett-Koehler Publishers, San Francisco, 1997.

27. Полани М. Личностное знание: на пути к посткритической фрилософии. М.: Прогресс, 1985. 345 с.

28. Massaro M., Bardy R., Lepeley M., Dal Mas F. Intellectual Capital Development in Business Schools. The role of "Soft Skills" in Italian Business Schools. 2013. URL: https://www.researchgate.net/publication/322989003_Intellectual_ Capital_Development_in_Business_Schools_The_role_of_Soft_Skills_in_Italian_ Business_Schools (дата звернення: 11.04.2020).

29. Черных С. И. Цифровая экономика и наука. Цифровая экономика. 2018. № 4. C. 73-86. dOI: 10.24411/2071-6435-2018-10038.

30. Dumay J., Guthrie J. Involuntary disclosure of intellectual capital: is it relevant? Journal of Intellectual Capital. 2017. № 1(18). P. 29-44. URL: https://doi.org/10.1108/ JIC-10-2016-0102 (дата звернення: 15.04.2020).

31. Jarrahi M. H. Social Media, Social Capital, and Knowledge Sharing in an Enterprise. IT Professional. 2017. № 1 (1). DOI: 10.1109/MITP.2017.265105759. 


\section{References}

1. Doklad o tsyfrovoi ekonomyke 2019. Sozdanye stoymosty y poluchenye vyhod: posledstvyia dlia razvyvaiushchykhsia stran [Digital Economy Report 2019: Value Creation and Benefit: Implications for Developing Countries]. Retrieved from: https://www.google.com/url?sa=t\&source=web\&rct=j\&url=https://unctad.org/en/ PublicationsLibrary/der2019_overview_ru.pdf\&ved=2ahUKEwiJ8bOk5-_oAhWEs4 sKHYKwAM8QFjAGegQIARAB\&usg=AOvVaw1ki0miE [in Russian].

2. Barkhordari, S., Fattahi, M., \& Azimi, N. (2019). The Impact of Knowledge-Based Economy on Growth Performance: Evidence from MENA Countries. Journal of the Knowledge Economy, 3(10), 1168-1182. DOI: 10.1007/132-018-052-4 [in English].

3. Torba, O. V. (2017). Intelektualnyi kapital yak obiekt bukhhalterskoho obliku: vyznachennia ta metodyka otsinky [Intellectual capital as an object of accounting: definition and methodology of valuation]. Internauka - Interscience, 2 (2), 62-67 [in Ukrainian].

4. Karimi, J., \& Walter, Z. (2016). Corporate entrepreneurship, disruptive business model innovation adoption, and its performance: the case of the newspaper industry. Long Range Planning, 3 (49), 342-360 [in English].

5. Zambon, S. (2006). Is there a disciplinary field called «intangibles and intellectual capital»? Journal of Intellectual Capital, 4 (7), 43-52. DOI: 10.1108/ jic.2006.25007daa.001 [in English].

6. Salykhov, B.V., Salykhova, Y.S., \& Olyhova, M.B. (2017). Kachestvo klyuchevyh form neyavnogo znaniya $\mathrm{v}$ sozdanii dobavlennoy stoimosti [The quality of key forms of tacit knowledge in value creation]. Natsyonalnye ynteresy: pryorytety $y$ bezopasnost - National interests: priorities and security, 1 (346), 48-61 [in Russian].

7. Fekri, Ali Sh. (2019). The board monitoring committees: an intellectual capital perspective. International Journal of Learning and Intellectual Capital (IJLIC), 4 (16). Retrieved from http://www.inderscience.com/info/inarticle.php?artid= 102632 [in English].

8. Yu, D., \& Zhou, R. (2017). Intellectual Management: An Integrative Theory. Journal of the Knowledge Economy, 3 (8), 929-956 [in English].

9. Faizi, W. \& Imamul H. (2020). Intellectual capital and corporate financial performance in India's central public sector enterprises. International Journal of Learning and Intellectual Capital (IJLIC), 1 (17). Retrieved from http://www.inderscience.com/info/ inarticle.php?artid=105323 [in English].

10. Reinsel, D., Gantz, J., \& Rydning, J. (2017). Data Age 2025: The Evolution of Data to Life-Critical. Don't Focus on Big Data; Focus on the Data That's Big. Retrieved from: https://assets.ey.com/content/dam/ey-sites/ey-com/en_gl/topics/workforce/ Seagate-WP-DataAge2025-March-2017.pdf [in English].

11. Cifrovizaciya ekonomika znaniy [The digital economy of knowledge]. Retrieved from: https://old.sk.ru/news/b/articles/archive/2018/04/20/cifrovizaciya-ekonomikiznaniy.aspx [in Russian].

12. Reinsel, D., Gantz, J., \& Rydning, J. (2018). Data Age 2025: The Digitization of the World. From Edge to Core. Retrieved from: https://www.seagate.com/files/wwwcontent/our-story/trends/files/idc-seagate-dataage-whitepaper.pdf [in English]. 
13. Sobko, O.M. (2014). Intelektualnyi kapital pidpryiemstva: kontseptualizatsiiafunktsionuvannia-rozvytok [Intellectual capital at enterprise: concept-functioningdevelopment]. Ternopil : Krok [in Ukrainian].

14. Stewart T.A. (1999) Intellektualnyiy kapital. Novyiy istochnik bogatstva organizatsii [Intellectual Capital. The New Wealth of Organizations]. Moscow: Academia [in Russian].

15. Edvinsson, L., \& Malone, M.S. (1997). Intellectual Capital. New York: Harper Business [in English].

16. Kogdenko, V.G. (2016). Analys integrirovanoy otchetnosty: intellectualnyi capital [Integrated reporting of the analysis: intellectual capital]. Economic Analysis: Theory and Practice - Economic analysis: theory and practice, 10, 53-67. Retrieved from: http://www.fin-izdat.ru/journal/analiz/ 61 [in Russian].

17. Andriessen, D. (2008). Intellectual capital: West-bound or East-bound? Journal of Intellectual Capital, 2 (9). DOI: 10.1108/jic.2008.25009baf.002 [in Russian].

18. Brennan, N., \& Connell, B. (2000). Intellectual capital: current issues and policy implications. Journal of Intellectual Capital, 3(1), 206-240 [in English].

19. Harrison, S., \& Sullivan, P. (2000). Profiting from intellectual capital - learning from leading companies. Journal of Intellectual Capital, 1(1), 33-46 [in English].

20. Li, Y., Song, Y., Wang, J. \& Li, C. (2019). Intellectual Capital, Knowledge Sharing, and Innovation Performance: Evidence from the Chinese Construction Industry. Sustainability, 11(2713). Retrieved from https://doi.org/10.3390/su11092713 [in English].

21. Litvinov, O.V. (2018). Vyznachennia sutnosti intelektualnoho kapitalu [Identification of significant intellectual capital]. Modern Economics - Modern Economics, 11, 98104. doi: 10.31521/modecon.V11(2018)-16 [in Ukrainian].

22. Topilnytska, Y. (2013). Intelektualnyi kapital: sut ta metodyka vymiriuvannia [Intellectual capital: the essence and method of measurement]. Derzhava ta regionuState and Regions, 2(71), 25-28 [in Ukrainian].

23. Bukovych, U., \& Uyliams, R. (2002). Upravlenye znanyiamy: rukovodstvo k deistvyiu [Knowledge Management: A Guide to Action]. Moscow: INFRA-M [in Russian].

24. Nonaka, I., \& Takeuchi, H. (1995). The Knowledge Creating Company. New York: Oxford University Press [in English].

25. Andriessen, D., \& Tissen, R. (2004). Nevesomoe bogatstvo. Opredelite stoimost vashey kompanii $v$ ekonomike nematerialnyih aktivov [Weightless Wealth. Find your real value in a future of intangible asset]. Moscow: ZAO «Olimp-business» [in Russian].

26. Sveiby, K.E. (1997). The New Organizational Wealth: Managing \& Measuring Knowledge-based Asset. San Francisco: Berrett-Koehler Publishers [in English].

27. Polanyi, M. (1985). Lichnostnoe znanie: na puti k post-kriticheskoi filosofii [Personal Knowledge: Towards a PostCritical Philosophy]. Moscow, Progress Publ [in Russian].

28. Massaro, M., Bardy, R., Lepeley, M. \& Dal Mas, F. (2013). Intellectual Capital Development in Business Schools. The role of "Soft Skills» in Italian Business Schools. Retrieved from https://www.researchgate.net/publication/322989003_ 
Intellectual_Capital_Development_in_Business_Schools_The_role_of_Soft_ Skills_in_Italian_Business_Schools [in English].

29. Chernykh, S.Y. (2018). Cifrovya economika y nauka [Digital economy and science]. Cifrovya economika - Digital Economy, 4, 73-86. DOI: 10.24411/2071-6435-201810038 [in Russian].

30. Dumay, J., \& Guthrie, J. (2017). Involuntary disclosure of intellectual capital: is it relevant? Journal of Intellectual Capital, 1(18), 29-44, Retrieved from: https://doi. org/10.1108/JIC-10-2016-0102 [in English].

31. Jarrahi, M. H. (2017). Social Media, Social Capital, and Knowledge Sharing in an Enterprise. IT Professional, 1 (1). DOI: 10.1109/MITP.2017.265105759 [in English].

Статтю отримано 1 травня 2020 р.

Article received May 1, 2020. 